\title{
KONCEPCJA WSTYDU W PISMACH ŚW. TOMASZA Z AKWINU ORAZ WYBRANYCH NURTACH PSYCHOLOGII WSPÓŁCZESNEJ
}

W literaturze naukowej, tak XX wieku, jak i współczesnej, można znaleźć dużo badań na temat zjawiska przeżywania wstydu. Interesuje się nim psychologia, psychiatria, socjologia, biologia ewolucyjna, etologia, medycyna, filozofia, a także inne dziedziny nauki. Zdecydowana większość psychologów zalicza wstyd do emocji, chociaż nie ma jednej definicji emocji, z którą wszyscy z nich mogliby się zgodzićl. Część badaczy uważa, że emocje stanowią podstawę systemu motywacyjnego i organizującego działania człowieka ${ }^{2}$. Ich przeciwnicy przekonują, że emocje, w większości odpowiedzialne za rozkład i dezorganizację zachowania, są jedną z przyczyn ludzkich problemów ${ }^{3}$. Podobnie jak w kwestii generalnego ujęcia emocji, nie ma zgody również co do definicji, istoty i funkcji wstydu. Współczesną psychologię emocji można porównać do różnokolorowych szkiełek leżących w pracowni witrażu, z których być może kiedyś złożony zostanie jeden witraż, natomiast dziś, wciąż jeszcze wiele

1 „Każdy wie, czym jest emocja, ale prawie niemożliwe wydaje się zdefiniowanie jej w sposób akceptowany przez wszystkich", K. D o d g e, Coordinating responses to aversive stimuli, "Developmental Psychology", 25(1989), s. 339.

2 Zob. C. E. I z a r d, Human emotions, Nowy Jork 2013, s. 43-64.

3 Zob. P. T. Y o u n g, Motivation and emotion: A survey of the determinants of human and animal activity, Nowy Jork 1961. 
podstawowych kwestii nie zostało ustalonych i wiele fundamentalnych założeń wstępnych i obszarów zainteresowań koegzystuje w tej nauce na równych prawach, nawet gdy dochodzą do sprzecznych wniosków. Jednomyślność psychologów ujawnia się jedynie w skąpym stwierdzeniu, że wstyd jest przeżyciem nieprzyjemnym.

Wstyd jest doświadczeniem towarzyszącym człowiekowi od zarania dziejów. Zajmowało się nim wielu myślicieli, m.in. jeden z największych filozofów chrześcijańskich - św. Tomasz z Akwinu. Autor ten patrzył na wstyd z punktu widzenia teologa, a nie psychologa. Nie zamierzał też pisać o tym, jak rozpoznawać i leczyć stany nerwowe u osób chorych. Głębia poznania duszy człowieka uprawnia do porównywania wstydu, jak rozumiał go św. Tomasz i jak rozumie go psychologia. Wspólnym obszarem zainteresowań dla św. Tomasza i psychologów są pytania o naturę, funkcje i źródła wstydu oraz fundamentalne zagadnienie szczęścia, zdrowia ducha i harmonii w życiu.

Konfrontując rozumienie wstydu przez wybranych, reprezentatywnych dla środowiska współczesnych psychologów z rozumieniem go przez św. Tomasza, można zaobserwować szereg fundamentalnych różnic, których źródłem są najogólniej rzecz ujmując ateistyczne założenia światopoglądowe psychologów, odmienne od założeń św. Tomasza. Niezatarty ślad w psychologii pozostawił Karol Darwin, oraz w mniejszym stopniu Zygmunt Freud. Ich poglądy stanowią historyczne podłoże i nieustannie inspirują badaczy tej nauki. Większość XX-wiecznych i współczesnych uznanych autorytetów w dziedzinie emocjonalności człowieka tłumaczy istnienie i sens emocji właśnie w oparciu o mechanizmy ewolucyjne (m.in. Tomkins, ${ }^{4}$ Frijda, ${ }^{5}$ Izard, ${ }^{6}$

${ }^{4}$ S. S. To m k i n s, D. L. N a t h a n s o n (red.), Affect Imagery Consciousness, The Complete Edition: Two Volumes, Nowy Jork 2008, s. 83-93.

5 N. H. Frij d a, The emotions, Cambridge 2001, s. 475.

${ }^{6}$ C. E. I z a r d, The face of emotion, Nowy Jork 1971, s. 54, 194. 
Plutchik ${ }^{7}$ ). Freudowskie poglądy również niezmiennie kształtują myślenie psychologów. $\mathrm{Z}$ tego powodu warto je przeanalizować.

\section{ROZUMIENIE WSTYDU W PSYCHOLOGII}

Spośród wielu różnych definicji wstydu funkcjonujących w psychologii wybrałam te, które są reprezentatywnym odzwierciedleniem różnorakich ujęć wstydu w literaturze naukowej. Jak uważa współczesna psychologia, mechanizmem, który wykształcił wstyd, był proces doboru zachowań przez ewolucję. Na poparcie tezy, ewolucjoniści podaliby np. zbieżne z ludzkimi fizjologiczne reakcje przeżywania wstydu u naczelnych. Darwin używał trzech terminów: wstyd, wina i nieśmiałość, ale wstyd i nieśmiałość miały dla niego znaczenie w zasadzie synonimiczne; wspominał o pewnych różnicach, ale ich nie zdefiniował. W swoich badaniach koncentrował się na ekspresji wstydu i uważał, że podstawową funkcję odgrywają w nim oczy8. Tomkins, jeden z pionierów psychologii emocji, opisał podobne cechy ekspresji wstydu: opuszczenie wzroku i obniżenie napięcia mięśni twarzy i karku, powodujące pochylenie głowy, które chociaż niespecyficzne wyłącznie dla niego, służą komunikowaniu uległości ${ }^{9}$. Z kolei osoby obserwujące taką postawę, reagują obniżeniem agresji, wzmocnieniem przywiązania i uznaniem przynależności zawstydzonego do grupy ${ }^{10}$. Elison definiuje wstyd jako afekt wyzwalany przez dewaluację przeczuwaną i niekoniecznie spostrzeżoną

${ }^{7}$ R. P lutchik, The nature of emotions, "American Scientist", 89(2001), s. 344-356.

8 C. E. I z a r d, Human emotions..., dz. cyt., s. 386.

9 S. S. To m k i n s, Affect Imagery Consciousness, t. II: The negative affects, Nowy Jork 1963, s. 143-144. Opis pozostaje w zgodzie z wcześniejszymi obserwacjami Darwina.

${ }^{10} \mathrm{D} . \mathrm{K}$ e $\mathrm{l} \mathrm{t} \mathrm{n}$ e r, L. H a r k e r, The forms and functions of the nonverbal signal of shame, w: P. G i 1 b e r t (red.), Shame: Interpersonal behavior, psychopatology and culture, Nowy Jork 1998, s. 88; N. H. Fr ij d a, dz. cyt. s. 27. 
czy zrozumianą, która powstaje na drodze interakcji społecznych ${ }^{11}$. Tracy i Robins twierdzą, że wstyd pojawia się, gdy ktoś zrobi wewnętrzną, ogólną ocenę swojej osoby, która prowadzi do powstania negatywnego uczucia wobec siebie ${ }^{12}$. Breggin definiuje wstyd jako odzwierciedlenie opinii innych o nas lub naszych własnych opinii o naszych relacjach z innymi, które wywoływane jest najczęściej przez krytykę lub porównania ${ }^{13}$.

Poza społecznym wymiarem, wielu psychologów zauważa prywatne, osobiste znaczenie oddziaływania wstydu ${ }^{14}$, jako sygnału adaptacyjnego skierowanego do samego siebie, ostrzegającego o obniżonej randze społecznej. W takim rozumieniu autorzy wiążą wstyd z percepcją dewaluacji ${ }^{15}$ lub rozerwania związków społecznych ${ }^{16}$. Zdaniem Elisona uniwersalność nie dotyczy wyłącznie poziomu fizjologicznego (u zwierząt obserwuje się podobne mechanizmy), ale też abstrakcyjnego, którym dla wstydu jest dewaluacja, rozumiana jako stracony, obniżony lub niższy niż oczekiwany status społeczny lub poziom akceptacji przez innych ${ }^{17}$. Jak widać, wielu badaczy, pozostających w nurcie psychologii ewolucyjnej, wiąże wstyd z interakcjami społecznymi, ponieważ pozycja osobnika w grupie, ma wpływ na jego dostęp do ograniczonych dóbr związanych $\mathrm{m}$. in. $\mathrm{z}$ reprodukcją. $\mathrm{Z}$ tego powodu rozpoznanie $\mathrm{i}$ radzenie sobie $\mathrm{z}$ obniżeniem rangi społecznej należą do fundamentalnych zadań życiowych. W tym

${ }^{11}$ J. E 1 i s o n, Shame and guilt: A hundred years of apples and oranges, "New Ideas in Psychology", 23(2005), s. 6.

12 J. L. Tr a c y, R. W. R o b i n s, Putting the self into self-conscious emotions: A theoretical model, "Psychological Inquiry", 15(2004), s. 114.

13 P. R. B r e g g i n, The biological evolution of guilt, shame and anxiety: A new theory of negative legacy emotions, "Medical Hypotheses", 85(2015), s. 21.

14 Zob. J. E1 i s o n, dz. cyt., s. 17-18.

${ }_{15} \mathrm{P}$. G i l b e rt, The evolution of social attractiveness and its role in shame, humiliation, guilt and therapy, "British Journal of Medical Psychology", 70(1997), s. 113.

${ }^{16}$ N. H. Frij d a, The place of apprisal in emotion, "Cognition and Emotion", 7(1993), s. 357-387.

17 J. E 1 i s o n, dz. cyt., s. 14. 
znaczeniu wstyd jest sygnałem członkostwa w grupie i akceptacji jej norm, jakiekolwiek by one nie były ${ }^{18}$.

Dla Freuda emocje były anachronicznymi sposobami wyładowywania się, a wstyd siłą kontrolująca destrukcyjne instynkty. Samo użycie sformułowania ,anachroniczne” w tym kontekście, sugeruje jego wiarę w heglowską koncepcję postępu i niedopasowania się istniejącej psychiki ludzkiej do obecnej rzeczywistości. Zastanawiające jest, względem czego jest ów syndrom wyładowania się „anachroniczny”? Względem siebie samego, ducha czasu, naszego zaawansowania ewolucyjnego w innych obszarach rozwoju, czy też wizji Freuda odnośnie tego, jak powinniśmy funkcjonować? Zasadne jest zatem pytanie o normę psychiki ludzkiej. Co stanowi „nowoczesny” sposób wyładowania się? Jakie normy społeczne powinniśmy przyjąć i kto je powinien określać? Wydaje się, że Freud wołał o dekonstrukcję współczesnych jemu norm społecznych, które krępowały człowieka, aby mógł wyzbyć się wewnętrznego napięcia. Intelektualni spadkobiercy Freuda uważają, że kluczem do zdrowia psychicznego jest odreagowanie emocji, a nie ich uporządkowanie względem samych siebie, czy też rozumu i woli.

Pomimo korzyści jakie ewolucjoniści ukazują dla grupy, to dla jednostki mechanizm jest bardzo szkodliwy i trudno sobie wytłumaczyć, jak w drodze ewolucji, jednostki, które się wewnętrznie i zewnętrznie dewaluowały, miały zyskiwać $\mathrm{w}$ reprodukcji, nawet jeśli zyskiwała na tym grupa. Wydaje się, że wewnątrz gatunku, czy plemion powinny zostawać przekazywane częściej geny tych osób, które nie okazywały wstydu, a nie tych osób, które wstyd okazywały i mechanizm ten nie powinien już istnieć. Niedawno (2015 r.) Breggin, zaproponował wyjaśnienie źródła i celowości promowania wstydu przez mechanizmy ewolucji ${ }^{19}$. „Ludzie są najbardziej społecznymi, współpracującymi, empatycznymi i kochającymi stworzeniami na Ziemi”"20. Z drugiej strony: „,bez wątpienia, jesteśmy najgwałtowniejszymi i najbardziej

\footnotetext{
18 Tamże, s. 16.

19 Zob. P. R. B r e g g i n, dz. cyt., s. 17-24.

20 Tamże, s. 18.
} 
autodestrukcyjnymi stworzeniami istniejącymi na Ziemi"21. Sukces (przetrwanie, rozmnażanie się itp.) wymaga z jednej strony opieki nad potomstwem, a z drugiej ostrej konkurencji z innymi ludźmi. Zdaniem autora ludzie są wyposażeni w naturalną skłonność do agresji i przemocy, która jest potrzebna, do obrony przed innymi, posiadającymi podobną naturę. „,Bez wbudowanego inhibitora ekspresji samowoli i agresji wśród bliskich, istoty ludzkie prawdopodobnie zabiłyby się wzajemnie w swoich rodzinach i klanach, a ludzkość byłaby znikającym punktem na ekranie ewolucji”22. Autor uważa, że wstyd, wina i lęk zostały wbudowane i utwierdzone w ludzkiej naturze przez mechanizmy ewolucyjne jako, ,inhibitory destrukcyjnych, instynktownych zachowań w rodzinach”23. „Wina, wstyd i lęk (...) hamują, powstrzymują, rozpraszają lub przekierowują ekspresję ogromnej samowoli i przemocy w naszych osobistych i rodzinnych relacjach"24, ale nie wobec obcych. Zdaniem Breggin'a, wstyd cechuje prehistoryczność, prymitywność, wywoływanie emocjonalnego bólu i prowadzenie do „bezradności, która obezwładnia aktywne próby zmierzenia się z konfliktem"25.

Na podobne konsekwencje wstydu wskazują Tangney i Dearing, kiedy piszą o wstydzie, jako o prymitywnym mechanizmie, który wywołuje ból i obezwładniającą bezradnośćc ${ }^{26}$. Uważają, że ból wstydu prowadzi ludzi w dwóch kierunkach: niechęci do świata spowodowanej przerzuceniem winy na innych lub odsuwania się od świata przez trwanie we wstydzie i jego internalizację (czego skutkiem może być np. depresja $)^{27}$. Psychologowie uważają, że na poziomie społecznym mechanizm ten prowadzi do zaprzeczenia, gniewu i agresji ${ }^{28}$.

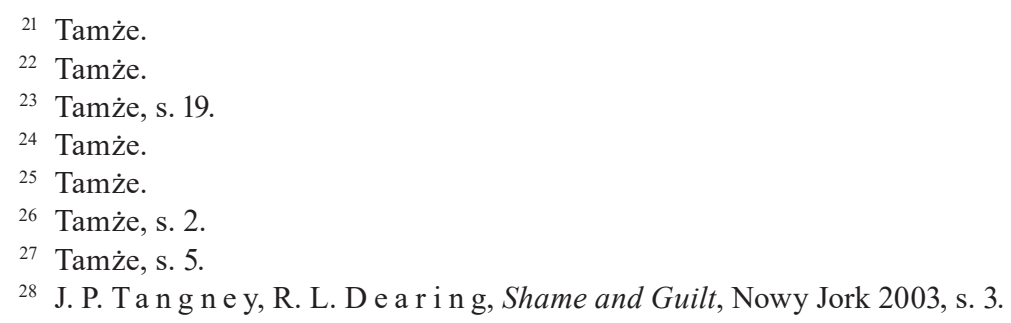


Podsumowując, dla zdecydowanej większości psychologów, wstyd jest przykrym i bolesnym wewnętrznym hamulcem naszych zachowań przeciw łamaniu norm grupowych (jakie by one nie były), który przez pokazanie akceptacji tych norm ma zwiększyć szansę gatunku na przetrwane, choć zbyt intensywne jego przeżywanie prowadzi do stanów chorobowych.

\section{WSTYD I NORMY SPOLECZNE}

Badania nad wstydem wskazują na dwa fakty. Pierwszy z nich, to uniwersalność kulturowa reakcji na przewinienie moralne, jakim obok winy jest wstyd. Drugim jest doświadczenie uniwersalnej refleksji o sobie, które dla psychologów jest nieuzasadnione i nie powinno nigdzie istnieć, a szczególnie nie powinno być obserwowane we wszystkich kulturach. Ta refleksja, jest rezultatem wniosku, że ja nie jestem spójny z wartościami. W swojej esencji, nie tylko formie bytu, ja i wartości, jesteśmy odmienni. Ja, mówiąc językiem religii, jestem grzesznikiem, a rozpoznaję wartości jako właściwe, i rozpoznaję powinność poddania się tym wartościom. Jest tak, nie tylko w sytuacji zbyt wysokiego mniemania o sobie, które w konfrontacji z rzeczywistością wstrząsa tak bardzo, że prowadzi do chorobliwych stanów, jakie opisują psychologowie. Człowiek pozostający w łączności ze swoim poczuciem wartości, widzi, że nie tylko jest winny (bo złamał daną normę), ale refleksja wstydu prowadzi do wniosku, że jego natura, on sam, jego wola nie jest w pełni spójna z normami. Mówiąc językiem religii, człowiek uświadamia sobie, że jego natura jest grzeszna nawet pomimo tego, kiedy nie grzeszy. Taka refleksja nasuwa problem do rozwiązania, ponieważ w założeniu ateistycznym świat wartości powinien być w pełni subiektywny i uwarunkowany kulturowo.

Tangney, profesor psychologii i badaczka wstydu, prowadziła obszerne badania wśród więźniów w USA. Stwierdziła, że ci więźniowie, których charakteryzuje wyższa podatność na przeżywanie wstydu, wypuszczeni na wolność po skończonym wyroku, częściej wracają ponownie do więzienia z powodu popełnienia kolejnych 
przestępstw. Więźniowie z niższą podatnością na przeżywanie wstydu mają statystycznie większe szanse powrotu do życia na wolności bez kolizji z prawem ${ }^{29}$. Korzystając z narzędzi do określania podatności na przeżywanie wstydu, w różnych badaniach stwierdzono współzależność pomiędzy wyższym poziomem przeżywania wstydu a ogólnie rozumianą nieuczciwością, np. kłamstwem wobec przełożonego ${ }^{30}$. Cohen i współpracownicy sądzą, że za pomocą stworzonego przez nich testu diagnozującego poziom podatności na wstyd, można będzie rekrutować pracowników, którzy z większym prawdopodobieństwem będą przestrzegać ustalonego porządku ${ }^{31}$. Wstyd, którego nadmierne przeżywanie znacząco koreluje z aktami łamania ustalonego prawa, jawi się tutaj jako szkodliwe zjawisko w psychice człowieka.

\section{WSTYD W UJĘCIU ŚW. TOMASZA Z AKWINU}

Św. Tomasz, wychodząc $\mathrm{z}$ innego założenia w sprawach fundamentalnych, wysnuł odmienne wnioski odnośnie do wstydu. Ujęcie wstydu św. Tomasza należy odczytywać na tle jego ujęcia człowieka, jako bytu i celów, jakie przed człowiekiem stawia Bóg. W części II Sumy Teologii, św. Tomasz analizował człowieka i jego naturę nie dla człowieka samego w sobie, ale dla pokazania w jaki sposób racjonalne stworzenia wracają do swojego Stworzyciela ${ }^{32}$. Teolog podkreślił w ten sposób, że człowiek został stworzony, aby osiągnął szczęście, a Stworzyciel w odpowiedni sposób go zaopatrzył

29 J. P. Tang ney, J. Stu ew ig, L. H a fe z, Shame, guilt, and remorse: Implications for offender populations, "Journal of Forensic Psychiatry \& Psychology”, 22 (2011) nr 5, s. 706-723.

${ }^{30}$ Zaobserwowano różną ,podatność” wśród ludzi na przeżywanie wstydu i zaprojektowano testy mające na celu jej diagnozowanie. Zob. np. T. R. C o h e n i wsp., Introducing the GASP scale: A new measure of shame and guilt proneness, "Journal of Personality and Social Psychology", 100 (2011), s. 947-966.

31 Tamże, s. 947.

${ }^{32}$ S. J. P o p e, Overview of the Ethics of Thomas Aquinas, w: S. J. P o p e (red.), The Ethics of Aquinas, Waszyngton 2002, s. 30. 
we wszystkie niezbędne środki, aby mógł go pragnąć, szukać i osiągnąć w swoim życiu, na różnych jego etapach ${ }^{33}$.

Św. Tomasz przypisał duszy rozumnej różne władze, a jedną z nich, intelektualną władzę dążeniową, nazwał wolą. Za sprawności woli, czyli cnoty, uznał roztropność, sprawiedliwość, męstwo i umiarkowanie. Spośród nich, cnota umiarkowania ma za zadanie porządkować uczucia władzy pożądliwej (pożądanie, przyjemność, niechęć, wstręt, ból) i umacniać wolę w kontrolowaniu różnych, ogólnie ujmując, pragnień ${ }^{34}$. Zdaniem św. Tomasza cnota umiarkowania ma dwa integralne składniki: „wstyd (verecundia), dzięki któremu człowiek wystrzega się sprzecznych z umiarkowaniem brzydkich czynów; oraz czesność (honestas), dzięki której ludzie kochają piękno umiarkowania"35. Odrzucił jednak możliwość nazywania wstydu cnotą w ścisłym znaczeniu tego słowa, ponieważ jest on uczuciem ${ }^{36}$. Widział wstyd, jako szczególną bojaźń ,przed tym, co jest brzydkie i hańbiące" ${ }^{37}$, w dwojakim znaczeniu, ponieważ ma za swój przedmiot dwa rodzaje brzydoty. Pierwsza brzydota ,(...) ma charakter występku, bo polega na wypaczeniu wolności (...). Druga natomiast, to kara polegająca na pogardzie (...)"38. W pierwszym znaczeniu wstyd jest bojaźnią przed niewłaściwym korzystaniem z wolności, które nie prowadzi ani do dobra, ani do szczęścia. Jest to bojaźń przed faktycznym złamaniem obiektywnego prawa naturalnego, jakie człowiek może poznać swoim rozumem. Nie jest to wyłamanie się z arbitralnie ustalonych reguł społecznych, lecz faktyczna kolizja $\mathrm{z}$ realną rzeczywistością. W drugim znaczeniu, wstyd jest bojaźnią przed brzydotą pogardy, czyli napiętnowaniem społecznym. Św. Tomasz rozważył również kwestię natężenia przeżywanego wstydu,

${ }^{33}$ Św. Tomasz wiedział, że są to tylko środki, a drogą jest Pan Jezus Chrystus, zob. ST III, q. 1-59.

${ }_{34}$ T. S t ę p i én, Wprowadzenie do antropologii filozoficznej św. Tomasza z Akwinu, Warszawa 2013, s. 151-154.

${ }^{35}$ ST II/II, q. 143, artykuł pojedynczy.

36 Tamże.

37 ST II/II, q. 144, a. 1, co.

38 ST II/II, q. 144, a. 2, co. 
co sugeruje możliwość stopniowania przeżycia wstydu, która wynika nie tylko z brzydoty czynu, którego dotyczy, ale również zależy od obserwatorów/świadków - czy są i jacy są ${ }^{39}$. Poziom zawstydzenia uzależnił św. Tomasz od wagi świadectwa, która z kolei zależy od jego poprawności albo od jego skutków ${ }^{40}$. Tymi, którzy mają pełniejszą wiedzę dotyczącą ocenianego i mogą wydać o nim prawdziwe świadectwo, są przede wszystkim jego bliscy. Z tego powodu silniejszy wstyd wywołuje ich negatywna opinia, niż opinia obcych.

Św. Tomasz zauważył jednak, że wstyd może pojawić się w sytuacji obiektywnie niezwiązanej z przewinieniem, ze względu na rozciągnięcie przymiotu braku czy poniżenia ze sfery postępowania np. do sfery materialnej. Stwierdził, że jest możliwe przeżywanie wstydu z związku z cnotliwym zachowaniem, gdy owo zachowanie nie znajduje akceptacji ze strony otaczających ludzi ${ }^{41}$. Przeżywanie wstydu w sytuacji niewłaściwej oceny obserwatorów, będzie jednak świadectwem polegania zbytnio na uczuciach, gdyż rozum podpowiada, że czynimy właściwie i nie należy się wstydzić. Choć takie uczucie nie jest sankcjonowane przez rozum, to istnieje możliwość przeżywania wstydu bez winy moralnej. Z drugiej strony, są sytuacje, w których należy się wstydzić, a otoczenie aprobuje brzydkie, występne postępowanie. A zatem, człowiek może się mylić w odniesieniu do przeżywanego przez siebie wstydu, może przeżywać go wtedy, gdy nie powinien lub nie przeżywać, gdy powinien. W swojej analizie św. Tomasz ważył rolę opinii innych ludzi, ale nie uwarunkował konieczności przeżywania wstydu do obecności innych osób. Wstyd może być dobry i potrzebny, także w sytuacji, gdy nie ma obserwatorów.

To może wydawać się mało znaczącą różnicą między św. Tomaszem a psychologami, lecz ma ona dalekosiężne konsekwencje. Trop psychologów mówiących, że wstyd przeżywamy przy łamaniu

39 ST II/II, q. 144, a. 3, co.

40 Tamże.

${ }^{41}$ Tamże. Może się to zdarzyć w szczególnych wypadkach, gdy dany czyn cnotliwy uchodzi w opinii ludzkiej za występek. 
jakichkolwiek norm, którzy nie zastanawiają się nawet, czy normy te są w zgodzie z prawem naturalnym i rozumem, czyż nie wprowadza nas wprost do kręgu myśli Machiavellego? To właśnie autor Księcia wielokrotnie doradza, iż by odnieść sukces należy troszczyć się o to, jak jesteśmy postrzegani, a nie by żyć cnotliwie (niezależnie od opinii innych).

Św. Tomasz dostrzegł też ograniczenie w działaniu wstydu. Mechanizm ochrony przed niemoralnym zachowaniem, zgodnie z antropologią św. Tomasza, jest tak doskonale zaprojektowany, że pomaga człowiekowi w różnym stadium jego rozwoju. Wstyd stanowi element władz zmysłowych - jest uczuciem. W człowieku, w którym wola nie jest jeszcze dobrze ukształtowana, w którym żądzą uczucia, ochrony można szukać w jego obecnym stanie rozwoju, tylko w uczuciach. Zatem, mówiąc językiem św. Pawła, jak długo człowiek pozostaje w niewoli ,żywiołów tego świata” (por. Ga 4, 3), w nich jedynych ma wsparcie (ale nie wyzwolenie i pełną dojrzałość), na poziomie na jakim się znajduje, aż nadejdzie czas jego wewnętrznego dojrzewania. Niedojrzałość polega na tym, że człowiek poddany jest swoim uczuciom, a nie woli. Gdy wola jednak osiągnie swoje sprawności, uczucia nie mają już tak dużego wpływu na działania człowieka. Wtedy wstyd, jako uczucie, również przestaje mieć wpływ, z całym dobrem i ograniczeniami jakie miał, choć potencjalnie człowiek mógłby się wstydzić, gdyby zaszła taka okoliczność. Dlatego, w sytuacji właściwego postępowania, gdy jest ono niesłusznie piętnowanie społecznie, wydoskonalony w cnocie człowiek nie ulega niesprawiedliwemu wstydowi, który chciałyby wzbudzić w nim uczucia.

Zatem, odwołując się do psychologów ewolucyjnych, św. Tomasz zgodziłby się ze stwierdzeniem, że wstyd powoduje hamowanie zachowań społecznie nieakceptowanych, ale wydaje się, że miałby co najmniej trzy zastrzeżenia. Pierwsze, dotyczyłoby zapewne granic rozumienia norm społecznie akceptowalnych. Św. Tomasz czyni rozróżnienie na wstyd przeżywany w sytuacjach, gdy moralnie należy się wstydzić, i kiedy wstyd przeżywany niesłusznie, w sytuacji gdy normy grupowe uznają czyn obiektywnie cnotliwy, czynem haniebnym. Tego rozróżnienia brakuje we współczesnej psychologii, 
która koncentruje się na różnicach w podatności na wstyd przeżywany społecznie lub pomiędzy wstydem a poczuciem winy, zupełnie ignorując obiektywną wartość moralną czynu. Drugie zastrzeżenie, jakie mógłby mieć św. Tomasz, to kontekst funkcjonowania norm grupowych, które w opinii psychologów reprezentują wypadkową sił ewolucyjnych i są, jak wspomniano wyżej, pewnym „kontraktem społecznym", niemającym funkcji celowej, jakim jest ochrona porządku duszy i wspomożenie jej w zabezpieczeniu ostatecznego szczęścia. Trzecie zastrzeżenie dotyczyłoby zapewne ograniczonej funkcji wstydu, jako instrumentu danego tym, którzy jeszcze nie wydoskonalili się w cnocie, a nie tym, którzy wydoskonalili się w nieczułości na nią.

Marcin Czekała, zwrócił uwagę na fakt, że lęk przed brzydotą, zdaniem św. Tomasza, jest powodowany nie tylko słabością w unikaniu zła moralnego, ale także upodobaniem w pięknie, które „w sposób szczególny jest jedną z racji istnienia wstydu" ${ }^{\prime 22}$. Autor nazwał wstyd najpiękniejszym uczuciem, bo to, co szpetne i brzydkie - a przed czym chroni wstyd - mija się z celem ludzkiego życia. Wstyd, który „W wyższym stopniu niż inne uczucia czyni ludzi prawymi”,43, jest konieczny w zdobywaniu moralnego piękna i „daje umysłowi bystre spojrzenie na dobra duchowe" ${ }^{\prime 4}$.

Rozważania św. Tomasza przypisują wstydowi przede wszystkim funkcję ochronną, jednak interpretatorzy podkreślając konieczność uprzedniości aktu wstydu w stosunku do szpetnego czynu, zauważają również jego trwanie w ciągu wykonywania całej czynności ${ }^{45}$ lub ból pozostający w konsekwencji popełnienia wykroczenia ${ }^{46}$. Cze-

${ }^{42}$ M. C z e k a ła, Apoteoza wstydu w filozofii św. Tomasza z Akwinu, „Człowiek w Kulturze", 14(2002), s. 222.

43 Tamże, s. 224.

44 Tamże, s. 226.

45 Tamże, s. 212.

${ }^{46}$ Człowiek wstydzi się przed (lęk) i po (ból) popełnieniu brzydkiego czynu; S. B ełc h, Objaśnienia tłumacza, w: To m a z z A k w in u, Suma Teologii, II/II, (tłum. S. Bełch), Londyn 1963, s. 198. Zob. także: J. W o r o n i e c k i, Katolicka etyka wychowawcza, tom II/1, Lublin 1986, s. 340. 
kała podsumował ujęcie wstydu w tomistycznej etyce, przypisując wstydowi funkcję oddzielania od niedoskonałości i przywracania harmonii pomiędzy człowiekiem i świętością ${ }^{47}$. Fritz Cates zauważa, że wstyd według św. Tomasza, nie zachęca do podążania za pięknem jako takim, ale ma funkcję hamującą, gdyż pomaga człowiekowi wystrzegać się ,manifestacji niesfornych pragnień w celu uniknięcia potępienia ze strony członków społeczności, na których opinii mu zależy"48.

\section{4. ŹRÓDŁA RÓŻNIC W UJĘCIU WSTYDU PRZEZ ŚW. TOMASZA I PSYCHOLOGIĘ EMOCJI}

Teoria ewolucji, jako ogólna zasada powstania gatunków, gdy zostaje przyjęta, nie może pozostać bez konsekwencji w rozumieniu ludzkiej psychologii. Nie jest możliwym przyjęcie tej teorii odnośnie powstania ciała ludzkiego, w tym mózgu i jednoczesne przyjęcie innej, która tłumaczyłaby zachowania ludzkie w oderwaniu od przyjętej wcześniej teorii powstania ciała. Jest tak dlatego, że teoria ewolucji jest koncepcją, która opisuje szereg procesów, włączając w to ukształtowanie się zachowań, komunikacji, ekspresji. Z tego powodu, przyjmując teorię ewolucji, należy konsekwentnie uwzględniać i tłumaczyć nią zachowania zwierząt i ludzi, co też czynią etologowie i psychologowie, korzystający ze spuścizny Darwina. Należy to zrobić zatem ze wszystkimi konsekwencjami intelektualnymi. W przypadku opisywanego w tej pracy problemu, konsekwencjami tymi są: geneza człowieka, celowość tej genezy, cel istnienia człowieka, cel istnienia mechanizmów, jakie człowiek posiada, mechanizm powstawania zachowań oraz, co za tym idzie, źródło wartości i moralności. Zgodnie $\mathrm{z}$ teorią ewolucji, geneza człowieka jest przypadkowa i nie ma założonego celu. Mówiąc kategoriami Arystotelesa, człowiek nie ma przyczyny celowej, m.in. dlatego, że nie ma nikogo, kto by proces

${ }^{47}$ M. C z e k a $\nmid$ a, dz. cyt., s. 212.

${ }^{48}$ D. Frit z C a te s, The Virtue of Temperance, w: S. J. P o p e (red.), The Ethics of Aquinas, Waszyngton 2002, s. 324. 
ewolucji uruchomił. Człowiek, jest tylko przystankiem na drodze do bardziej zaawansowanych gatunków, które za miliony lat go zastąpią. $\mathrm{Z}$ tego powodu, ciało nasze nie jest finalnym zamysłem Boga, lecz wypadkową zmian w genach swojego gatunku i w obrębie innych gatunków, które doprowadziły do sytuacji, w której układ genów, jaki określa obecnie nasze ciało, stał się najbardziej konkurencyjny. Śledząc tę myśl dalej widzimy, że nie ma obiektywnego celu życia człowieka, poza reprodukcją, a i to z perspektywy jednostki nie musi być niczyim celem, bo z jakiej przyczyny człowiek, który poznał i uwierzył koncepcji Darwina, miałby świadomie podporządkować się nagle globalnym mechanizmom?

Jeśli nie ma obiektywnego celu życia, poza reprodukcją dla zachowania gatunku, człowiek jest wolny, by samodzielnie określać cel swojego istnienia oraz samodzielnie określać prawa i zasady swojego działania. Jest to wolność do samookreślania się, jak pojmują ją egzystencjaliści szkoły Sartre'a ${ }^{49}$, który chciał właśnie wyciągnąć wszystkie możliwe konsekwencje z zajmowania pozycji ateistycznej.

Zgodnie z psychologią ewolucyjną i idącą z nią antropologią, mechanizmy jakie kierowały ukształtowaniem się ludzkich zachowań, były tymi, które dały naszemu gatunkowi największą szansę na przeżycie i dominację. W związku z tym moralność powinna być, i najczęściej jest, postrzegana przez ewolucjonistów jako mechanizm wypracowany przez człowieka. W związku z tym należy ją rozpatrywać, tak jak wszystkie inne społeczne normy, jako element, który albo daje/dawał przewagę w konkurencji pomiędzy osobnikami i gatunkami, albo element, który przeszkadza/przeszkadzał w utrzymaniu przewagi człowieka. Także koncepcje dobra i zła, zostały wymyślone i nie ma żadnego autorytetu poza nami samymi, który mógłby je określać. Czy możemy być więźniami samych siebie? Trzymać klucz do celi w której jesteśmy zamknięci? Zapewne nie, i konsekwencją moralną jest przyjęcie tak popularnego obecnie relatywizmu wartości, subiektywizmu moralnego. Jeśli nie ma prawa moralnego, to

49 S. E. S t u m p f, Socrates to Sartre: A History of Philosophy, b.m.w. 1999, s. 476. 
mówiąc krótko, nie ma się czego wstydzić, więc wstyd nie ma sensu. Jeśli natomiast prawo moralne istnieje, to wstyd nabiera szczególnie ważnej funkcji ochronnej, zgodnie z tym, co pisał św. Tomasz.

\section{ZAKOŃCZENIE}

Czy jakakolwiek synteza mądrości św. Tomasza i współczesnej psychologii jest możliwa? Choć wydaje się, że na poziomie teorii i praktyki współcześni psychologowie i Teolog z Akwinu stoją na przeciwnych biegunach, to jednak przykład psychiatrów Terruwe i Baars, którzy wykorzystali założenia tomistycznej antropologii i freudowską ideę represji ${ }^{50}$ do terapii nerwic opartej na integracji psychicznej, dowodzi inaczej. Konflikt prowadzący do represji, zdaniem tych psychiatrów, powstaje albo pomiędzy co najmniej dwoma sprzecznymi uczuciami dotyczącymi tego samego przedmiotu (np. pożądaniem i lękiem przed przedmiotem pożądania lub przed samym pożądaniem), albo uczuciem i wolą (pragnienie cukierka u cukrzyka, lęk przed konieczną operacją). Represja słabszego uczucia w konflikcie pomiędzy uczuciami może być przyczyną nerwicy. Ich zdaniem budzenie różnych uczuć przez ten sam przedmiot jest czymś naturalnym, ale nienaturalna jest sama represja. Zdrowie psychiczne i harmonia nie zastaną naruszone dopóki pragnienie zmysłowe będzie zgodne z rozumem i wolą. Chroniczny jest stan, w którym nie można posiąść upragnionego przedmiotu i nie zostaje on dobrowolnie odrzucony przez osąd rozumu. Uczucie tłumione pozostaje w napięciu, ale uczucie tłumiące nie pozwala zadziałać rozumowi, ponieważ wyprzedza go w działaniu i w związku z tym uczucie stłumione pozostaje poza kontrolą rozumu. Integracja psychiczna w terapii różnych nerwic polega na usunięciu represji i przywróceniu

${ }^{50}$ A. A. Terruwe i C. W. Baars docenili intuicję Freuda dotyczącą represji, ale inaczej wyśnili mechanizm jej powstawania. Zob. A. A. Te r r u w e, C. W. B a a r s, Integracja psychiczna, o nerwicach i ich leczeniu, Poznań 2002, s. 58. 


\section{właściwej kontroli rozumu i woli, chociaż jej szczegółowy przebieg zależy od rodzaju nerwicy ${ }^{51}$.}

\section{Streszczenie}

Niniejsza praca analizuje pojęcie wstydu w tekstach św. Tomasza w kontekście wybranych współczesnych ujęć psychologicznych. Celem pracy, jest skonfrontowanie rozumienia wstydu przez wybrane nurty współczesnej psychologii z ujęciem św. Tomasza, pokazanie zasadniczych różnic i wyjaśnienie ich źródła. Hipotezą pracy, jest twierdzenie, że ze względu na odmienne rozumienie antropologii, tego kim jest człowiek, jaki ma cel, w jaki sposób jest do osiągnięcia tego celu przysposobiony, oraz na odmienne rozumienie etyki, źródła moralności i co za tym idzie podstaw ładu społecznego, znacznie więcej będzie dzielić obie strony, niż je zbliżać. Kluczowe różnice spodziewano się odnaleźć w źródle, funkcji, oraz ocenie użyteczności wstydu.

W czasie prowadzonej analizy zaobserwowano szereg fundamentalnych różnic. Źródłem tych różnic są ateistyczne założenia światopoglądowe psychologów, którzy w przeważającej mierze są psychologami ewolucyjnymi, ateistycznymi humanistami. Przyjmując założenie, że człowiek jest dziełem przypadku w procesie ewolucji, konsekwentnie przyjmują oni także, iż środowisko w jakim się porusza, jak i on sam, jest wyłącznie materialne oraz, że to właśnie środowisko jest jedynym źródłem warunkowania mechanizmów ludzkich zachowań. Wszystkie mechanizmy emocjonalne, szczególnie obserwowane spójnie we wszystkich kulturach na całej planecie, muszą mieć wytłumaczenie ewolucyjne. Spójnego z teorią ewolucji i racjonalnie satysfakcjonującego wytłumaczenia jednak nie odnaleziono. Wstyd wydaje się być dla części psychologów bezsensownym, szkodliwym anachronizmem.

Św. Tomasz, wychodząc z innego założenia, wysnuwa odmienne wnioski. Ponieważ zakłada celowe stworzenie człowieka przez absolutnie moralnego Stwórcę wszechrzeczy, który zaprojektował go tak, by doszedł do szczęścia w Nim, świat wartości jest nie tylko obiektywny, ale ma niezwykłą wagę. Św. Tomasz opisał mechanizm wstydu, jako logicznie działające uczucie, które pomaga tym, którzy poddani są władzom zmysłowym, jako hamulec (bojaźń) przed popełnieniem złego czynu. Dla św. Tomasza, wstyd jest zatem mechanizmem, celowym, nakierowanym na osiągnięcie dobra nie tylko materialnego, ale przede wszystkim

${ }_{51}$ Tamże, s. 59-60. 
duchowego (wspieranie cnoty umiarkowania). Psychologowie współcześni odrzucają całą koncepcję św. Tomasza, gdyż odrzucają jego metafizykę. Hipoteza pracy została potwierdzona. Propozycja dalszych badań dotyczy zbadania możliwości wypracowania dowodu istnienia obiektywnego porządku moralnego na podstawie antropologicznego dowodu na uniwersalność wstydu i mechanizmu jego funkcjonowania we wszystkich kulturach.

\section{The Concept of Shame in the Writings of St. Thomas Aquinas and in Selected Trends of Modern Psychology Summary}

This paper examines the concept of shame in the writings of St. Thomas Aquinas, in the context of selected contemporary psychological approaches. The aim of this work is to compare the understanding of shame by selected approaches of modern psychology, with that of St. Thomas, and to show fundamental differences and explain their sources.

The source of these differences are atheistic worldview assumptions made by psychologists, who are predominantly evolutionary psychologists and atheistic humanists. Assuming that man is the product of a chance in the process of evolution, they also consistently assume that the environment in which he moves, like himself, is only material and, it is the environment that is the only source of conditioning mechanisms of our behavior. All emotional mechanisms, especially observed consistently across different cultures must have an evolutionary explanation. Shame seems to be for many psychologists pointless and harmful anachronism.

St. Thomas, starting from different assumptions, draws different conclusions. Because he assumes the creation of man by absolutely moral Creator of all things, who designed man so that the man could find happiness in Him, the world of values is not only objective, but it is of extreme importance. St. Thomas described the mechanism of shame, as a brake (fear), which is a feeling effecting those, who are subjected to feelings, to prevent them from committing an evil act. For St. Thomas, shame is therefore a purposeful mechanism, which aims to achieve good not only material, but above all spiritual (support the virtue of temperance). Many psychologists today reject the whole concept of St. Thomas, because they do not accept his metaphysics.

Słowa klucze: św. Tomasz z Akwinu, psychologia, wstyd, emocje

Key words: St. Thomas Aquinas, psychology, shame, emotions 
Nota o autorce: Agnieszka Grabowska, ukończyła studia magistersko-inżynierskie z biotechnologii na SGGW w Warszawie, teologię na UKSW w Warszawie i Studium Życia Rodzinnego w Łodzi. Pracowała przy badaniach naukowych nad genetycznym podłożem chorób układu krwionośnego i onkologicznych.

\section{Bibliografia:}

Bełch S., Objaśnienia tłumacza, w: Tomasz z Akwinu, Suma Teologii, II/II, tłum. S. Bełch, Londyn 1963.

Breggin P. R., The biological evolution of guilt, shame and anxiety: A new theory of negative legacy emotions, "Medical Hypotheses", 85 (2015), s. 17-24.

Cohen T. R. i wsp., Introducing the GASP scale: A new measure of shame and guilt proneness, "Journal of Personality and Social Psychology”, 100 (2011), s. 947-966.

Czekała M., Apoteoza wstydu w filozofii św. Tomasza z Akwinu, „Człowiek w Kulturze", 14 (2002), s. 211-227.

Dodge K, Coordinating responses to aversive stimuli. "Developmental Psychology", 25 (1989), s. 339-342.

Elison J., Shame and guilt: A hundred years of apples and oranges, "New Ideas in Psychology", 23 (2005), s. 5-32.

Frijda N. H., The emotions, Cambridge 2001.

Frijda N. H., The place of apprisal in emotion, "Cognition and Emotion”, 7 (1993), s. 357-387.

Fritz Cates D., The Virtue of Temperance, w: Pope S. J. (red.), The Ethics of Aquinas, Waszyngton 2002, s. 321-339.

Gilbert P., The evolution of social attractiveness and its role in shame, humiliation, guilt and therapy, "British Journal of Medical Psychology", 70 (1997), s. 113-147.

Izard C. E., Human emotions, Nowy Jork 2013.

Izard C. E., The face of emotion, Nowy Jork 1971.

Keltner D., Harker L., The forms and functions of the nonverbal signal of shame, w: P. Gilbert (red.), Shame: Interpersonal behavior, psychopatology and culture, Nowy Jork 1998.

Plutchik R., The nature of emotions, "American Scientist”, 89 (2001), s. 344-356.

Pope S. J., Overview of the Ethics of Thomas Aquinas, w: Pope S. J. (red.), The Ethics of Aquinas, Waszyngton 2002.

Stępień T., Wprowadzenie do antropologii filozoficznej św. Tomasza z Akwinu, Warszawa 2013.

Stumpf S. E., Socrates to Sartre: A History of Philosophy, b.m.w. 1999. 
Tangney J. P., Dearing R. L., Shame and Guilt, Nowy Jork 2003.

Tangney J. P., Stuewig J., Hafez L., Shame, guilt, and remorse: Implications for offender populations, "Journal of Forensic Psychiatry \& Psychology”, 22 (2011) nr 5, s. 706-723.

Terruwe A. A., Baars C. W., Integracja psychiczna, o nerwicach i ich leczeniu, Poznań 2002.

Tomkins S. S., Affect Imagery Consciousness, tom II: The negative affects, Nowy Jork 1963.

Tomkins S. S., Nathanson D. L. (red.), Affect Imagery Consciousness, The Complete Edition: Two Volumes, Nowy Jork 2008.

Tracy J. L., Robins R. W., Putting the self into self-conscious emotions: A theoretical model, "Psychological Inquiry", 15 (2004), s. 103-125.

Woroniecki J., Katolicka etyka wychowawcza, tom II/1, Lublin 1986.

Young P. T., Motivation and emotion: A survey of the determinants of human and animal activity, Nowy Jork 1961. 